\title{
MORAL CHARACTER, MORAL AGENCY AND THE GENRES OF THE REPRESENTATION OF OTHERS ${ }^{(1)}$
}

\section{David Epston}

Co-Director, The Family Therapy Centre. Auckland, New Zealand

How to reference this article:

Epston, D. (2019). Moral Character, Moral Agency and the Genres of the Representation of Others. Revista de Psicoterapia, 30(114), págs 171-194. https://doi.org/10.33898/rdp.v30i114.325

\begin{abstract}
This article is an Address given in San Antonio, Texas where some ways of approaching conversations that highlight people's moral character in relation to the Problem that harasses them are discussed.

Several stories are offered to help reflect on people's ability to see themselves as worthy of their own respect and the respect of others. Such moral respect not only allows what we might call "moral agency" but also allows us to exercise it more freely.

Conversations about people's “wonderfulness" and conversations that begin with virtues, not problems, are ways to subvert the dominant representations that the problem offers.

It is about recovering people's lives from everything that stripped them of what I will call "their moral character". Possibly, in tune with what has been called the preferred identity, people prefer to be represented in terms of their moral character, their moral virtues. This also has to be made manifest in what we call counter-documents and a set of therapeutic letters is offered to exemplify this. Perhaps the present article can be seen as a counter document, where the need to rescue the moral virtues of people is made manifest, even before speaking of problems.
\end{abstract}

Keywords: narrative therapy, moral agency, preferred identity, conversation, counter document.

\section{Resumen}

El presente artículo es una conferencia ofrecida en San Antonio, Texas donde se plantean algunas formas de acercarse a conversaciones que destaquen el carácter moral de las personas en relación con el Problema que las acosa.

Se ofrecen varias historias que ayudan a reflexionar acerca de la capacidad de las personas de verse a sí mismas como dignas de su propio respeto y del respeto de los demás. Tal respeto moral no sólo permite lo que podemos llamar "agencia moral" sino también poder ejercerla más libremente.

Las conversaciones acerca de las "maravillosidades" y las conversaciones que comienzan con las virtudes y no con los problemas, son modos de subvertir las representaciones dominantes que el problema ofrece. Se trata de recuperar las vidas de las personas de todo aquello que las despoja de lo que voy a denominar "su carácter moral".

Posiblemente, en sintonía con lo que se ha venido denominando la identidad preferida, las personas prefieren ser representadas en términos de su carácter moral, sus virtudes morales. Esto también tiene que quedar de manifiesto en lo que llamamos contradocumentos y se ofrecen un conjunto de cartas terapéuticas para ejemplificar esto. Quizás el presente artículo pueda ser visto como un contradocumento, donde se pone de manifiesto la necesidad de rescatar las virtudes morales de las personas, incluso antes de hablar de los problemas.

Palabras clave: terapia narrativa, agencia moral, identidad preferida, conversación, contradocumento. 
To deliver a Plenary Address to such an august body I assumed a responsibility to think beyond what I had thought about so far. I did so to show my gratitude as I have taken your invitation to address you as an honour. And I confess I lost several month's sleep wondering how I might live up to that.

So let me sketch my intentions for this address. I want to introduce you to the vocabularies and ideas I will be drawing from in contemporary scholarshipphilosophy, sociology, anthropology and a smattering of literary studies. For that reason, some of what I may have to say may be unfamiliar but I hope by the end of my address, that will no longer be the case. I am going to speak of moral character, moral agency and genres of representation of the other. But more importantly I will tell you the story of how I came to such concerns, those seemingly chance events that afterwards you might say you were destined to realize. That somehow or other you were prepared for it. What the scientist Louis Pasteur referred to in 1854 as 'the prepared mind'. Pasteur wrote in this regard: "Have you ever observed to whom accidents happen because in the fields of observation, fortune favours the prepared mind 2 ".

My story, or perhaps stories, have to do with some of the accidents that happened to me and how my mind was prepared for them and how this led me to consider how those who seek our assistance might be represented in a way that hearten them to engage the vicissitudes of their lives- what we my refer to as 'Problems' by virtue of their moral character. And with what results because I will admit to you I was surprised as you may be to hear what I have to say.

First let me tell you about Maureen, aged nine and her mother, Beverley who consulted my colleague David Marsden in Los Angeles.

"Maureen's step-grand-father had died of a heart attack only days after visiting Maureen and her family after which her world grew precarious. For six months and counting, she had not been able to stop thinking about his last visit, plagued by the idea that he might be alive today if only she had paid closer attention. Surely there must have been warning signs. Of late, she had become increasingly pre-occupied with the health of others- her grandmother, her mother, and her younger sisters. Maureen went to bed most nights accompanied by troubling thoughts and awoke in the morning to a sense of dread. In recent weeks, she had taken to calling her mother at work to make sure she was alright unable to wait for her safe arrival home. She had begun to collect momentos of her family such as ticket stubs and receipts so if they died, she would have keepsakes of them".

Here are some abstracts from the transcript of their meeting. Please join me in getting to know Maureen and Beverley and their moral deliberations about loss, love and ethics and consider their moral character in relationship to the 'Problem'.

"David: Has worry been weighing you down?

Maureen: I guess.

Mother: She is a sensitive child. She is the eldest and most vulnerable in some ways. I told her Nana has a cold. It's nothing. She and her Nana are very close in 
spite of the fact that my mother lives in Chicago. They email and we are going back in spring to visit. Mo (nickname for Maureen) is the most excited.

David: Beverley, is Maureen's deep feeling for her Nana part of her sensitivity? Mother: Oh, there is no question about that.

David: I wondered if that was the case. Beverley, can you tell me more about her sensitivity before Worry came in to the picture?

What was her sensitivity like?

Mother: The first thing that comes to mind is how much she has always cared for everyone especially her two younger sisters.

David: Is it possible that Worry has been taking advantage of her Sensitivity of late? Before Worry showed up, did you think of her sensitivity differently?

Mother: Yah, I thought of it as a gift in some ways.

David: If it is a gift and not meant for Worry's purposes, for what purpose might it have been intended?

Mother: For love!

David: What brings tears to your eyes as you consider Maureen's capacity to love?

Mother: It's just her capacity for love. She is my special girl.

David: Maureen, are you especially gifted at loving?

Maureen: Yah.

David: How good are you at loving your nana and your sisters?

Maureen: Really good!

David: And how do you get to be so good at loving?

Maureen: Because I was born close to Valentine's day. Isn't that right Mommy?

Mother: That's right honey. February $10^{\text {th }}$. You are a valentine baby!

David: Were you touched by love from the very beginning?

Maureen: I already knew how to love before I was born.

David: If you could, would you give away some of your sensitivity?

Maureen: You can't give it away!

David: But what if you could? Imagine you had three wishes, would you use one to be less sensitive?

Maureen: No!

David: Why not? Isn't it harder this way?

Maureen: Yah!

David: Would it be better to care a little less and in that way, still care but Worry wouldn't be able to sneak in if something hard happened?

Maureen: No, it's better to care.

David: Even if it hurts sometime.

Maureen: Yes, because if you care more about people, they care more about you.

David: If you care more, how do you bear it when you lose someone?

Maureen: I don't know.

David: Does Maureen take after you? Does caring a lot run in your family? 
Mother: She does take after me matter of fact. It is not the easiest road, I can tell you!

David: And how have you lived with your sensitivity through the years?

Mother: I'd have to think about that. I wish I could give her an easy answer.

David: I appreciate your honesty, Beverley, and I have to admit that I do not have the answer myself. Maureen, I want to ask you but I don't know if it is fair to ask a nine year old such a question but anyways, here goes. Is it worth it to care so deeply?

Maureen: Yah!

David: Can you try to explain it to me? What makes it worth it?

Maureen: I don't know..it's just better to care.

David: Is your grandfather watching you from above?

Maureen: Mommy says he's in heaven.

David: Is it possible that he feels your love all the way from Los Angeles to heaven?

Maureen: He can feel me.

David: Do you think he knows what you are going through?

Maureen: Yah!

David: What do you think he understands?

Maureen: That I miss him.

David: Why is it worth to care as much as you do? To have the gift of sensitivity when it comes at such a price?

Maureen: Because it is better to love.

David: Beverley, do you agree with your daughter? That this is the bottom line. That it's all about love even if there is a cost?

Mother: Yes it is. She's my girl"”.

Do you wonder what might have been prescribed for her if in the most recent round of the Diagnostic Statistical Manual, such grief had been successfully declared to have been a diagnostic entity with well marketed pharmacology to pacify her? Would she, her mother and David been able to engage in a discussion of her moral character in relation to the Problem that was besetting her? And for Maureen to care instead of wishing away her sensitivity to others? Would it have been possible for Beverley to have reason to now revalue it as a gift she was bestowing on her beloved eldest daughter when she was reassured it was all about love, even if there is a cost?

After meeting with a very scholarly family in Oaxaca in Mexico in 2004, Margarita Boom wrote me an email telling me that the interview had had an extraordinary effect on all her family members when she sent around to them a transcript of the interview. Her proposed title for a book chapter she intended to write about this was- 'Reclaiming the Dignity and Honour of Our Ancestors', a family which had been disgraced by the humiliations of her father's mental health crises and recurrent hospitalizations ${ }^{4}$. These were not entirely familiar terms to an English 
speaker like myself and perhaps that as much as anything else caught my attention. However, on reflection Michael White and I had been concerning ourselves about something very similar from our very first conversations in the early $80 \mathrm{~s}$. In fact, I found those Latin terms 'honour' and 'dignity' uncanny. By this time, we had encountered the American philosopher, Hilde Lindeman Nelson's term, 'respectworthiness', a word in fact that she had invented for her specific purposes. It had not previously existed in the English language. By that she meant "the capacity for a person to convince themselves and others firstly that they were worthy of their own respect and secondly of others"4. She went on to argue that such moral respect not only allows moral agency but also to exercise it more freely ${ }^{5}$.

This allowed me to return to the very beginnings of narrative therapy, especially when I chanced to come across at the Auckland Central Library Thomas Kuhn's History of Scientific Revolutions ${ }^{3}$ which Michael and I were reading as well as many others in the early 80s. I decided to reread it. Kuhn proposed that every 'paradigm shift' in science at any rate was consumed by a 'puzzle' which would be inventors set out to solve or at least unpuzzle. I thought to myself, "What was our puzzle?”. I thought this would be hard to answer but it didn't take very long at all for me to seek and find the puzzle. I am going to refer to it as a 'crisis of representation' which emerged in the social sciences in the 70s and was driven since then $b \quad y$ feminist, queer, cultural studies and indigenous critiques of the 'representation of the other'. Both Michael and I found the dominant modes of representation that dominated our professions as offensive, degrading, humiliating and above all else stripped the person concerned of what I am going to refer to as 'their moral character'.

In fact, recently I met a woman, now aged thirty-nine, at an undergraduate Social Work program here in New Zealand where I lecture. She approached me to inform me that she had met Michael once and me twice twenty-nine years ago and it was because of those two meetings that she had enrolled for the degree. I recalled Marie as a ten year old suffering from anorexia and when I met her, her parents and two older brothers, a hospital admission had been scheduled in three days time. Her family had arranged an urgent appointment with me to see if such a prospect could be averted. As it turned out, she commenced eating immediately upon leaving my office. In fact, they had gone directly from there to a nearby chain restaurant. I met her and her family one month later and Michael White who had been visiting me in Auckland accepted my invitation to join us.

This is what she told me all those twenty-nine years later.

I knew that because I could get over this with my family's help, I could help others. But first I wanted to find a wonderful partner and two wonderful children that we now have. Now that they are almost ready to go to high school, it is now time for me to do what I determined do all those twentynine years ago. And I remember every question you asked, especially the ones about how caring and giving my granny was and how I might be taking after her and I guess I am. And I guess that's why I am here today. 
She told me her parents wished me well and wanted me to know that they had saved to that day my letters as well as Michael's letter. Can you imagine my enthusiasm to recover these letters? I had to wait several months as her parents were travelling overseas. This only whetted my appetite.

I want to read to you my second letter to her parents dated March 20, 1985. Dear Don and Cheryl:

I am writing to indicate to you both my respect for you as parents. I still believe that you provided the conditions for Marie to face up to and overcome the anorexic life style she was rapidly heading for. You deserve my congratulations. This of course does not mean there might be the odd hiccup in the future. This is to be expected. But I have supreme confidence in you both to deal with anything that comes your way. Your daughter is fortunate to have such wonderful parents and it comes as no surprise to me that she herself is fully aware of this.

I am honoured to know you and your family who has tackled such a Problem that can cost young women some or all of their lives.

Fond regards,

David.

If I hadn’t realized before, this vindicated how such conversations contribute to young people's philosophies of being.

Before I proceed, I am going to ask you to tolerate for a minute or two a very personal inquiry which I doubt, when you awoke this morning, you thought you might be considering at my address or at any other of the workshops you will be attending at this conference.

Imagine this if you will:

You have lived a very long life...70 or 80 years or more. Over these years you have achieved much of what you had aspired to do, according to the purposes you had for your life. You know that the time that remains to you is short although you are not experiencing any pain or suffering at all. You are determined that you will advise those who will organize your funeral how you wish to be known by those you expect to attend your funeral- immediate family, close friends and colleagues. Let me put it another way- how you wish the life you have lived to be represented. You know only too well there are very few modes or genres of representation. Would you prefer those you select to speak about the living of your life according to your moral character, your moral virtues? Or would you rather prefer to arrange for a post-mortem psychiatric assessment that will be read aloud as a representation of your life? If you are like me, you will find this a very easy choice. You will want to be represented in terms of your moral character, your moral virtues. Why is this so when we as professionals represent the people that consult us in a very specific and particular genre of representation. This form of representation which has markedly grown in its influence over the last fifty years makes little or no reference to matters of moral character or moral virtues, the terms you and I would have wished to be 
known by. From hereon, I will refer to this mode of representation as 'pathologizing' and the one you chose for your funeral and obituary as 'characterizing'.

By the same token, have you ever thought to know those who consult you in the same way you would seek at the end of your life to be represented and known? And if you were to do so, would they come to know themselves any differently than they might have otherwise?

I know Michael White and I were at pains to resolve such a conundrum and come to know them in the same terms and by similar means to how we might want to be known. For them to be in Hilde Lindeman Nelson's coined phrase- 'respectworthy' rather than blameworthy or shameworthy. By the time, we had encountered the American feminist philosopher, Hilde Lindeman Nelson's term, 'respectworthiness', a word in fact that she had invented for her specific purposes. It had not previously existed in the English language. By that she meant 'the capacity for a person to convince themselves and others firstly that they were worthy of their own respect and secondly of others ${ }^{5}$ ". She went on to argue that such moral respect not only allows moral agency but also to exercise it more freely (Nelson, 2001).

Let me quote from Whitaker and Cosgrove's (2015) Psychiatry Under the Influence: Institutional Corruption, Social Reform. This book emanates from the Edward J. Safra Center for the Study of Ethics at Harvard University. And in it, the authors quote Sam Crisp who wrote a review of the DSM5 as if it was a novel.

This is what he writes:

This is a story without any of the elements that are traditionally held to constitute a setting or a plot. A few characters may make an appearance but they are nameless spectral shapes, ones that wander in and out of view as the story progresses briefly embodying various illnesses before vanishing as quickly as they came. A sufferer of major depression or of hypochrondiasis might eventually be revealed to be the same person but mostly the boundaries between diagnoses keep the characters apart from one another. The idea emerges that everyone's illness is somehow their fault, that it comes from nowhere but themselves, their genes, their addictions or inherent insufficiency. We enter a strange shadowland where for someone to engage in prostitution isn't to do with intersecting environmental factors, gender relations, social class, family and social relationships but a conduct disorder. If there is a normality here it is near catatonia. The DSM5 has no definition of happiness other than the absence of suffering. A normal individual in this book is tranquillized, bovine-eyed mutely accepting everything in a sometimes much in the way about it. The vast absurd excess of passion that forms the raw matter of art, literature, love and humanity are too distressing. It is easier to stop being human and plod on as a heaped collection of diagnoses with the body vaguely attached (p. 137).

The philosopher Aristotle, who lived from 384-322 BC, in Book 1 Chapter 9 in his study of Rhetoric proposed two parallel modes of representation: the Base 
and the Noble, by which he intended to distinguish between 'virtue' and 'vice'. He wrote:

We now have to consider virtue and vice, the noble and the base. These are objects of either praise or blame. The noble is that which is both desirable for its own sake and also worthy of praise. If this is a true definition of the noble, it follows that virtue must be noble since it is both a good thing and also praiseworthy. The forms of virtue are justice, courage, temperance, patience, munificence, magnanimity, morality, gentleness, prudence and wisdom. (Aristotle, 1984, p. 47).

I now want to turn to medical anthropology and literary theory before we proceed any further to introduce you to other distinctions between 'characterizing' and 'pathologizing'. I am referencing here E.M. Forster in his classic Aspects of the Novel published in 1956. According to Forster, "flat characters in their purest form are constructed around a single idea or single quality" (what we might refer to as a diagnosis). "When they are identified as such, flat characters never waver; they do exactly what you expect them to do, no more and no less". "Flat characters", Forster notes, "can be described in a single sentence. Round characters by contrast possess multiple qualities, shadowy ambiguities and outright contradictions. Most importantly, round characters are capable of change unlike flat characters" (Forster, 1956).

I realize now that this dilemma of these conflicting modes of representation'pathologizing' draws only upon on one's vices and flattens one's character if not stripping it naked to a mere caricature. By contrast, 'characterizing' draws upon one's virtues to engage with one's vices and according to Aristotle is always the moral of the story.

Let us consider another distinction which I also hope will serve my purposes as well. Here I am drawing on Arthur Kleinman, psychiatrist, anthropologist, Prof of Social Health and Global Medicine and Psychiatry at Harvard University.

He writes in his classic text, The Illness Narratives: "The contribution of professional orthodoxy to inadvertently heighten the passivity and demoralization of patients and their families is all too common".

He argues furthermore: "Not only to the effects of illness demoralize, the treatments themselves demoralize" (Kleinman 1989).

Arthur Frank, the Canadian sociologist and himself a cancer sufferer, then went on to distinguish between 'demoralization' and 'remoralization' (Frank, 2004). 'Demoralizing' for Frank was the dehumanizing experience of being admitted to a hospital feeling they were being reduced to an object of medical inquiry and treatment. In narrative terms these people with fears and woundedness found themselves renamed in the hospital inquiry by way of diagnosis and treatment. "Remoralization", he says, "refers to the process by which patients regain their humanity, particularly by being central to the story they were part of". Let me put it another way: They are a character in their own life, instead of being deleted, 
instead of being turned in to a nobody or a never body.

So let me tell you how fortune favoured my prepared mind in 1994. On previous flights travelling from Detroit to Boston, the flight seemed over before it had begun. I am used to twelve hour flights from Auckland to Los Angeles and the same duration on my repatriation. Nothing could have been further from my expectations on this particular winter's day. The first sign that all was not well was the continual delaying of the flight and learning from my fellow passenger that there was a blizzard up and down the East Coast of the United States. And that Boston was at the heart of it. Some hours later, we boarded the airplane to be told that we would not be taking off until Boston airport could inform us we had a designated snow-cleared runway. Apparently the crews there were only able to keep one runway open and they did not want planes circling the airport for fear of a collision. In the most upbeat voice you could possibly imagine, a flight attendant announced we were going to have fun in the meantime. They had obviously trained for such an eventuality. I was soon to learn how different it is to sit for several hours in an airplane on the ground than to when it is flying and how many people get claustrophobic fears as a consequence. After an hour or so, the knuckles of the passenger seated next to me started turning white from holding on to her hand rests so tightly as well as I could hear her begin over-breathing. I rushed to her rescue by engaging her in a conversation to distract her and myself to our circumstances. Well, we did finally reach Boston Airport eight hours later than the scheduled arrival time.

During this period of time I had worried myself sick about arriving so late as I knew my sponsor was expecting 100+ attendees at my two day long workshop that would begin nine in the morning the next day. Still arriving at my colleague's home at about ten pm, I presumed that now all would be well. However, almost immediately the 'bad' of my flight turned to a 'worse'. My colleague, Sallyann asked me to phone Linda from her supervision and training group who had arranged for a family to join me in a live interview the next day. "It’s a psychiatric emergency!" she told me. In the nicest possible way, I enquired about such arrangements as I remembered nothing about them. Sallyann went to her computer and returned soon after with a hard copy of an email explicitly requesting she arrange a live interview early on the first day of the two day workshop. I pleaded with Sallyann that this would be impossible. "I am wreck! A psychiatric emergency! I am not up to it!" Sallyann sympathetically suggested I phone Linda right away.

Before I did, I retired to the toilet to vomit and if I could avoid that to give myself a moment or two to consider my predicament. Almost immediately I had a flash of inspiration. I phoned Linda asking her not to tell me what the Problem was until she heard my proposal. Why? Because if I heard the Problem, I knew I would have felt the urgent requirement to respond to it the next morning. My proposal was that given my stressful flight and my anxiety about arriving at all, I could only count on myself as " $50 \%$ of a therapist". I requested she submit the following proposal to the family. That since we had two days scheduled for the workshop and I am 50\% 
of a therapist, would they be willing to come two days instead of the one? And that by the end of the two days they would have experienced $100 \%$ of a therapist. Linda returned my call not long afterwards and said that the family appreciated my situation and that arrangement would be fine with them.

My relief was short lived because now I would have to figure out how I would get through an hour long interview without knowing what the Problem was. How could I make this interview highly pertinent to a family in the midst of a 'psychiatric emergency' as well as 100 plus attendees who had come expecting to witness a live interview? No one could possibly stretch the social pleasantries of getting to know one another over that hour long meeting.

It is well know that in such circumstances, 'necessity is the mother of invention!' If ever if I was required to invent something quickly, tonight was the night. Tomorrow at ten am would be its testing ground. There was not much time but my exhaustion ushered me to what seemed a deep sleep. However, I awoke with a resolution to my dilemma. How about getting to know them by getting to know them 'against' the Problem rather than 'with' the Problem? Essentially I chose an inquiry that by implication would ask them what they collectively had to bring to bear to the matter at hand- the 'psychiatric emergency'? What histories could be made available that could very likely be at odds with the pathologizing histories that would be commonplace in an interview such as this? I formulated my question as this:

'Suzie(aged thirteen), can I get to know you outside of the Problem so we all get to know what you have got going for you that you can put against the Problem that is besetting you? And tomorrow we will find out everything there is about the Problem? I will be asking you about your talents, abilities, your moral character and generally what people think is wonderful about you'.

Attempting to meet the exigencies of their situation the best way I could think of, I had no idea at the time how radical such a proposal would turn out to be. In some ways, I was turning the conventional order of the 200 plus year convention of the assessment interview which usually has two stages: 'What is the Problem?' and 'What do we do about it?' backwards or upside down. Here I was asking first: 'What have you got to put against the Problem' with 'What is the Problem' to follow. One father commented aloud near the end of such an interview several years later: "David you are telling the story backwards!". I had no idea that this would lead to anything other than merely getting through the day. However my personal circumstances serendipitously forced me to think otherwise and come up with doing something I had never done, nor considered doing, ever before. In retrospect, I think of it as an unusual natural experiment. But there was more to come that made this an extremely unusual experiment.

On meeting we negotiated what must have seemed a very unusual arrangement and the family gave their wholehearted consent for me to proceed. I now had ahead 
of me an hour long interview in which the way had been ethically cleared to reveal what they had to put against the Problem. Essentially this was to be their side of the 'match up' with the as yet unknown Problem, that is unknown Problem to me; they knew it only too well. But now they had the right to go first and the Problem came second. This would for some of us be akin to when a sports commentator before the game 'matches up' the competing teams and on the basis of this might predict the outcome. I was determined to lavish every possible means at my disposal to represent this family as a worthy adversary for the 'psychiatric emergency' they were facing which, let me reassure you, was as yet entirely unknown to me. But as a consequence of this strange first meeting, the family was no longer facing such a Problem with their heads bowed in shame or anticipated 'social defeat'. Now they might return the gaze of the Problem, seeing themselves through their family's restored dignity and honour. Might they see themselves differently through such an interview format? To be honest, what was of most concern to me was just getting through this hour long interview and giving myself another day to recover my wits. To my delight, this meeting turned out to be entirely different than my forebodings. Serendipitously, I had chanced upon the means I had been seeking to get to know people as 'respectworthy' rather than pathological. Each member of this family was able to impress themselves upon me in ways that would have been impossible through a conventional interview format. I came away thinking how fortunate and honoured I was to know each and every one of them. Solidarity had been engendered between us rather then splintering them in to individual parts according to the individualizing bias of clinical interviews.

In some ways, this hour long interview was somewhat akin to what the legendary Harvard sociologist, Sara Lightfoot Lawrence refers to as 'the art and science of portraiture' (Lawrence \& Davis, 1997).

This is how she describes it:

I wanted to create a narrative that bridged the realm between science and art merging the systematic and careful description of good ethnography with the evocative resonance of fine literature. I wanted the written pieces to convey the authority, wisdom and the perspectives of the subject but I wanted them to feel they although it may not look like them, but somehow managed to reveal their essence. I wanted them to experience the portrait as both familiar and exotic so that in reading them, they would be introduced to a perspective they would not have considered before. And finally I wanted them to feel seen, fully attended to, recognized, appreciated, respected and scrutinized. I wanted them to feel both the discovery and the generosity of the process as well as the penetrating and careful investigation (Lawrence \& Davis, 1997, p. 37).

The remedy for me was to structure a time and place and absolutely divide what the person and their family might bring against the Problem and the Problem and what it had brought in its turn to the family. I reordered the usual order of the 
clinical interview in acknowledgement of my exhaustion and divided it up in to two separate meetings considering that each meeting was constituting one half of a typical hour long meeting. With this I summed up with what I believed to be half of the first interview, 'Well, we now know what you have individually and collectively to put against this Problem that is besetting you. But tomorrow I will learn all there is to know about the Problem'. I can recall just how much I was anticipating this second half of the meeting. Whatever the Problem was, I felt it shrinking as the family's dignity and honour increased. My anticipation was interrupted later that day with Jane, the mother, phoned to say they had to cancel the Sunday meeting as an uncle had died and they had to leave to drive several hour's drive north to be on hand for the funeral.

Many in the audience were concerned about what had transpired and there was considerable debate. Given the contentious nature of these interviews- the one they had attended and the one the family had cancelled, it was very fortunate that Linda had already scheduled an appointment at seven pm on the following Monday. Remember the interview had taken place at ten am on Saturday. What happened? The psychiatric emergency was their 13 year old daughter's conviction when she awoke on school days that she was blind and consequently unable to see and thereby unable to attend school. Over this period of time, several consultations with opthamologists had yielded nil diagnoses. Her diagnosis was 'conversion disorder' On Monday, she awoke and without further adieu went off to school. Her mother was completely satisfied with this outcome. The emergency was over. I suspect if the second half of the interview had actually taken place, I would not have been able to grant such an effect to merely half of what I had intended-an hour long interview regarding what was wonderful about each and every one of them. But there was much more to come but now my mind was well prepared!

Not too long after having returned to New Zealand, Marie rang me in tears to forewarn me what I might expect when I met her husband, Jim and her eleven year old son, Billy. Billy was in serious trouble in just about every arena of his life. He had been kicked out of his school class, after his teacher had previously taken to shunning him by either having him face the back wall or turning away from him on any other occasion. Jim, by the same token, had renounced Billy as his son and was now considering writing him out of his will. The Auckland Regional Authority, which provides public transport, was also going to the extraordinary lengths of taking legal action against him to deny him the right to travel on their buses. How could a young person be in quite so much trouble? Marie was so perplexed and distressed by the very telling of Billy's 'trouble' that she began to sob inconsolably. I tried to reassure her as best I could that 'nothing was impossible' when at last she asked if I thought Billy was 'a hopeless case'.

Meeting them at my front door was odd. As Marie led her 'family' inside, Jim and Billy avoided each other as best they could, and again in my waiting room. I led them to my interview room. Jim rushed in ahead of everyone else and started 
scrutinizing the paintings on my wall. No one had ever deliberated over these paintings with such connoisseurship before. Marie followed, distressed and humiliated, taking her seat and then began to plead with Billy who was reluctant to enter my room. Finally, he did, sitting where his mother indicated by her side, but couldn't meet my eyes, or anyone else's. It was only after Billy had committed himself to his seat that Jim immediately turned away from scrutinizing the paintings and deliberately seated himself so he couldn't 'see' Billy.

As is my custom, I commenced our meeting with as much hospitality as I could, given the pall that had fallen over the room. "Look, I don't want you to think I don't consider Billy's trouble as a matter of great concern". I then turned towards Billy and said: "However, Billy, if I were you, I wouldn't want to meet a stranger my age through the trouble the 'trouble' has got you in. Jim and Marie, do you mind if I get to know your son through how you knew him before he got tangled up in all this trouble?". Billy, for the first time, raised his downcast eyes to meet mine and stared at me, somewhat bemused, through his Harry Potter glasses. Both Jim and Marie, not knowing quite what to expect, gave their consent for me to proceed with my enquiries.

I turned first to Marie. "Marie, what would you like me to know about Billy that proves to you that you are a wonderful mother, or at least the kind of mother you dreamed you would be when you were pregnant with Billy?". That caught Marie off guard and seemed to break her out of her dejection. Her response took some time and consideration. But when she did, she mentioned his kindness. "Could you tell me one story about Billy's kindness that would be worth 100 stories? That from such a story I would really understand what you mean when you say he is kind”. She responded quickly, telling a story of how when some Kosovar refugee children came to his school, he had gone out of his way to befriend a class-mate, despite the barriers of language. And he had even gone so far as to invite this boy home to meet his family. Her disconsolation now gave way to some measure of pride.

I refused to leave the matter there. Turning to Jim, I asked: "Jim, is he by any chance a chip of Marie's block?". His smile, tinged with pride, told me I had guessed right. Responding to my enquiries, he told of all "the lame dogs" she had cared for, including an elderly neighbour for whom she provided meals on a daily basis. When I asked Marie if it was an accident that Billy showed such kindnesses to his Kosovar class-mate, she was willing to admit that that was unlikely. In fact, when I asked Jim, he said that it would have been entirely predictable that Billy should grow up showing such kindness, having witnessed his mother's caring ways day in and day out.

It was early in the year and hot. Jim was wearing a very short sleeved t-shirt. Noticing a tattoo of a military regiment on Jim's shoulder, I asked if he had been in the military. In fact, he had and took great pride in his current involvement with young people in the Sea Cadets.

"Jim, do you drink down at the Returned Serviceman's Club every now and 
again?". He did. "You know when your mates are bragging about their sons and it comes around to your turn, what would you brag about Billy before he got into so much trouble?”. Admittedly, he pondered my question for some time before replying: "His creativity!”. "Jim, by any chance did he inherit that from you?”. Jim was pensive and then shook his head, before some sort of gleam of recognition came to him. "Not from me, but from my brother. You won't believe this, but he makes his living as a potter and sculptor selling ceramic sheep shit!”.

"What?”. I asked, but immediately considered the 50,000 million sheep in New Zealand, roughly how many sheep pellets a sheep produces per day and how the Ministry of Research and Development might consider turning these into a very fast buck. I speculated about this and everyone laughed. Jim brought me down to earth on this get rich quick scheme for New Zealand. "No, he lives in rural England and people buy these ceramic sheep pellets as some sort of joke. And you know it brings in enough money for him to be a sculptor". Well, we all to admit that this certainly bore all the hallmarks of creativity, and by now even Billy was joining in the fun. I then pursued the earlier matter regarding Billy, but once again referencing my questions to Jim. "Jim, how does Billy take after his uncle in terms of family creativity?”. Jim no longer shunned Billy, but spoke kindly of the story-telling and paintings that he had been doing since he was 'just a toddler'. "Have you saved any of his early works?”. I asked. Jim looked chagrined as he told me that in his repudiation of.

Billy, for the first time, interjected and what he had to say first confused and then stunned us into a momentary silence. He said: "Let's go home. This is over. I have just stopped all my trouble. There will be no more of it". Marie and Jim both turned towards Billy, looking as if they were hearing things, and continued to stare at him. I tried to save the day by asking Billy what he could possibly mean by making such assertions. "Billy, are you trying to have your mother and father believe that you have renounced trouble? After all, Billy, there is not much more 'trouble' an eleven year old could get into from what your mother told me over the phone. By the way, what 'trouble' did you get into to have the Auckland Regional Authority taking you to court? A court case surely must be costing them thousands in lawyer's fees. Billy, tell me, how far did you travel on a bus and how often?". He told me he bussed to school every day. "How far?" I asked. "About a mile and a half," he said. "Billy, how much 'trouble' can you get into in a mile and a half?”. I asked. "Screaming!" he told me. Marie nodded her head to reassure me that Billy could and did scream. Billy looked at me as if I wasn't getting his point. "Yah, it's over, I'm not going to do it anymore". I turned to Jim and Marie: "Surely, Billy has got quite a job on his hands to prove to both you and his school-teacher that he means it?". They agreed that this would be quite an undertaking on Billy's part. "Billy, do you think everyone will just take your word for it, or do you think you will have to prove it to them?”. Billy admitted that it was certainly unlikely that either his father or his school-teacher would believe him, although he thought he 
had a better chance with his mother.

I then asked Billy if he was serious, would he be willing to write a letter to that effect to the teacher who had recently expelled him. I assured him that I would be only too happy to give him a hand preparing it. "Billy, I'll ask you questions and type up your letter. Marie and Jim, would you be willing to act as witnesses to such a document?”. Billy willingly joined in such a project; his parents were still baffled, but agreed to go along with it.

We came up with a long list of measures he was willing to take to 'put pressure on myself' rather than 'putting pressure on his teachers'. And if he failed the pressure he was now only too willing to endure, he stated what amends he would make.

I am happy to report that when we met one month later for our last meeting that his new teacher, in a letter to our meeting, declared him entirely unproblematic.

It read as follows: "I have seen no evidence of problems whatsoever. I am enjoying his company in Room 15 and finding his academic work well up to standards".

When I asked everyone of them to give me account of this, Marie told me that "this is the most wonderful thing that has ever happened in my life". Jim concurred saying "it was as if someone turned on the light!"; consequently he had dropped his case with his lawyer to drop Billy out of his will. But Billy had the last word in our discussion and it was certainly a thoughtful one.

“Turning twelve changed me. I said to myself-why don't I make the best of this term so I can leave a good reputation behind me when I go to high school next year”. I never really learned what the Problem had been. It just seemed too beside the point to even ask (Epston, 2009).

So far, I had found by these two 'natural experiments' that establishing the moral character of the young person and genealogically relating it to the family, culture and community they came from, had meant far more to the Problem than I could have guessed or even anticipated. In the case of Billy, the Problem seemed to vanish instantaneously whereas in the case of Katie, the 13 year old, it seemed to disappear overnight. Day in, day out over the next ten years, I experimented with the prospect of actively finding ways to engage young people's 'wonderfulnesses' as expressed in their talents, abilities, visions, morals, commitments, family traditions but in general using the Aristotelian term, their virtues in developing some sort of engagement with the Problem.

In the time that remains, I would like to tell you about Jan and Ron and their ten year old daughter, Kelly.

Jan and Rob were beside themselves with concern that their 10 year old daughter, Kelly had "an obsessive-compulsive disorder". They based this on the fact that she was spending hours on end in the toilet and requiring them to buy toilet paper by the case lot. All their efforts to talk her out of the problem, let alone out of the toilet, failed as she would become "hysterical" if they tried to interfere with what they referred to as "her rituals". Their concerns were shared by Kelly's school-teacher who had beseeched them to "get some help for her before it is too 
late”. Also because this was a one toilet family, when Kelly took up residence in the toilet and would not come out no matter what, her parents were becoming extremely inconvenienced and had to get a bucket for their use at such times. But this was a mere frustration compared to their concerns for what was becoming of their kindly but "sweet hearted" daughter.

I learned of a recent occasion when Kelly's girlfriends came over on a Saturday afternoon to hang out together. For a shy girl, Kelly cherished these occasions when she was able to entertain her friends on her home ground. Her mother told how she literally was "beside herself" an hour or two before they were to arrive, peering out the window or continually asking her mother for an update on the time. Jan, in particular, loved overhearing Kelly and her girlfriends "chirping away in her bedroom or tv-room like a box of birds". She admitted to just keeping out of their way and sight as she derived so much pleasure from doing so. At such times, her fears about Kelly's future were allayed. However, what Jan had put so much hope came to a sad and seemingly dead end almost overnight. Even with her girlfriends on hand and ready to play, Kelly was required to retire in to the toilet. Her girl-friends, after waiting what seemed an inordinate amount of time, called their parents to come and pick them up. Her girlfriends were then reluctant to come and Kelly was now as reluctant to invite them. No amount of parental encouragement could change her mind. She was adamant that she would never invite them over ever again. Jan and Rob were heartsick over what they saw as "our last hope for Kelly coming right" and they reluctantly had to admit that "this is beyond us". They had exhausted every possible remedy they could think of and others could recommend, internet searches, nutritional approaches, and good old-fashioned soul-searching.

The meeting began with Jan dutifully informing me that I should not expect Kelly to say anything at all. "You don't speak to strangers, do you darling?". Kelly seemed relieved by her mother absolving her of any responsibility to speak for herself. That was in no way inconvenient as we began with the wonderfulnesses inquiry. However, Kelly was willing to nod 'yes' or 'no' to indicate her agreement or disagreement of any claims made by her parents as to her wonderfulnesses.

This is an abstract from a transcript of the conversation that occurred about forty-five minutes in to our first meeting together after Jan and Ron brought the loss of her girl-friends to my attention. Kelly sat with her head bowed and her hands laying over her lap, appearing to me like a repentant sinner which was a very poor match for her parents who looked to me so pained that they were unable to do anything to palliate her suffering. But by now, I was no longer a stranger as Kelly would respond to my queries.

David: Kelly, what did you think of the problem shutting you away in the toilet and having your girl-friends miss out on the fun you usually have when you have a play-date together?

Kelly (looking humiliated and speaking in a disconsolate tone): I don't know. David: Say you were on your own playing with your girlfriends, what do you 
think would have happened?

Kelly: We would have had fun.

David: What kind of fun would you have? play-fun, talk-fun, joking-fun, or just plain 10 year old girl-fun?

Kelly (she now appeared to be coming out of trance, especially when she smiled while responding): 10 year old girl-fun.

David: I am so much older than you. What do 10 year old girls get up to these days to have fun?

Kelly: I don't want to talk about it (looks disconsolate again after her spirits seemed to rise at the beginning of this sequence of questions).

David (giving Kelly a time-out, I turned to her parents): Jan, what kind of fun would you have expected Kelly and her girl-friends to have?

Jan: I can't tell you in words how much fun they might have had but they would be chirping away like a box of birds.

David: What kinds of birds, Jan?

Jan (laughing): canaries, budgies, perhaps even tuis (footnote as this is a NZ bird).

David: As Kelly's mum, did it do your heart good to overhear this 'box of birds' chirping away under your roof?

Jan: Boy, did it ever!

David: How about you Rob?

Rob: For me is was more than their chattering; it was their laughter. We don't hear Kelly laugh very often so it did my heart good to hear her and her mates laughing out loud.

David: Kelly, do you mind me asking you if this Problem killed your joys with your girl-friends?

Kelly: What do you mean?

David: Do you not know what a 'killjoy' is? Jan and Rob, do you know what a 'killjoy' is?

Rob (readily coming to my rescue): Yah, sure! A killjoy is someone who hates people having fun and I guess 'kills their joys'.

David: That sounds about right but should we look it up in the dictionary? (I consult the Oxford Concise Dictionary which I have handy for just such purposes). Here it is: "One who spreads gloom over social enjoyment". What do you think, Kelly?

Kelly (somewhat more engaged as this conversation has now taken an unexpected tack): Yah, I suppose so.

David: By the way everyone, is that a good way to refer to this Problem? Or can you think of a more apt description?

Jan: That's really good David!

Rob: Spot on...I'd say!

David: How about you Kelly? 
Kelly: I suppose that's right.

David: If after giving it some thought over the next week or two you come up with something better, will you email me and let me know?

Kelly: Okay.

David (returning to the wonderfulness of caring for others that was very elaborated, firstly her practice of it and then, its genealogy): Kelly, I know your mum and dad have just told me with such respect and regard about your wonderfulnesses, especially that you have the virtue of caring for others, including those younger than yourself and smaller than yourself like cats, dogs, goldfish right down to spiders despite the fact that so many people, even adults, are freaked out by spiders. And the story they told how you went along with your young cousin, Amelia, when she had to go to the outdoor toilet when you were camping on the beach last summer and rescued all the spiders and freed them outside so no harm would come to them.

And I learned that your care and love for others have been passed down from your grannies on both your mum and dad's sides of the family. Both grannies are well known for lending anyone in need a helping hand at their churches and in their neighbourhoods. Your mum and dad said this caring missed out their generation but you are an exact chip off your grannies' blocks. I am not so sure I should take their word for that as they seem pretty caring parents to me.

Why I am mentioning this is I am feeling sorry for a 'killjoy' Problem as it must be full of gloom and not have a clue about having any sort of fun. In fact, as your dad suggested, this Problem seems to hate people having fun like you and your girlfriends. Can you imagine what it must be like for your Problem to only know gloom and doom? Kelly, do you in any way feel sorry for this 'killjoy' Problem?

Kelly (now speaking with a newfound measure of authority): I guess so. No fun at all would be no fun. And to kill other people's joys isn't good.

David: That's for sure. Would you be willing to lend the 'killjoy' Problem a hand and help it have some fun?

Kelly: I suppose so but how do you do that? (she had nodded her head to the left and her query was quizzical rather than querulous).

We had a lengthy discussion about how she and her parents toilet-trained their dog, Martha by showing her where to go and where not to go. And that had worked out just fine. And how she lent her younger cousin, whose parents were staying over, a hand to help Jan make some chocolate-chip cookies. What seemed common to each story of coming to the aid of another was 'showing' the person/ animal companion in need how to do something. We arrived at a pedagogy of 'showing' more than 'telling'. Or at least 'showing first' and 'telling later'. Everyone contributed to this discussion although Kelly did come to the fore but Rob and Jan were always on hand to back her up with their own accounts of lending a hand to someone in need. Here we were adumbrating the engagement Kelly and her family might have with such a Problem but here rather than toilet-training it, she might instead show it how to have fun. 
From our wonderfulnesses inquiry, I had also been informed that her Auntie Sarah was regarded "as a laugh a minute". Jan and Rob were sure that if she tried to have a career as a stand up comedian, she could have made a go of it. Sarah was a primary school teacher. Whenever Auntie Sarah got together with Kelly, no matter how reticent or worried she had been beforehand, they both were soon "falling about laughing” with Kelly in fact laughing louder than her aunt.

On further jocular inquiry, we concluded that although the 'killjoy' Problem did "get around', it mainly seemed to live in the toilet. And i suppose that told us where she might best undertake her mission to lend the Problem a hand.

Now we began transmogrifying these wonderfulnesses in to a family practice, with Kelly obviously taking the lead. We all agreed that living in the toilet was not the most likely place for anyone or any Problem to meet friends and have some fun together. By the same token, we concurred that toilets were pretty lonely places because generally you used them one at a time.

David: Kelly, do you think we just have to go where the Problem lives? That we can hardly expect it to come out in the lounge for you to lend it a hand and show it how to have a good time?

Kelly: I suppose so.

David: Rob and Jan, how many people do you estimate could fit in to your toilet?

Rob (getting the gist of this conversation and by now, the parents' pained expressions were long gone): Three of us but it might be a tight fit.

David: Is it possible to invite Auntie Sarah and squeeze her in to the fun-making?

Jan: She actually lives in Tauranga (a three hour drive to the south-east).

David: If she knew everything we had been talking about, do you think you could call her on the phone and she could tell some jokes to you three and the 'killjoy' Problem. This way you would be feeding two birds with one worm. Do you know that saying, Kelly?

Kelly (somewhat perplexing but trying to get it): Dunno.

David: Don't worry about it. I just made it up. But let me tell you what I mean by it. You could catch up with your auntie and laugh yourself silly and at the same time show the 'killjoy' Problem that life is all not doom and gloom. Would you be willing to lend the Problem a hand so it doesn't have to go through it's life as a kind of 'misery guts'?

Jan (somewhat anxious awaiting Kelly's response): Will you do it darling?

Kelly (smiling with what I guessed was anticipation of the task ahead of them): Okay!

Jan and Rob said they would have no problem making the arrangements and finding a suitable time for showing the problem fun and connecting with Auntie Sarah. As Rob said about his sister: "Wherever and Whenever Sarah is around, there is sure to be some fun and jokes!”.

We had some discussions of her style of humour and how that "Irish sense of humour' went back generations all the way to Kilkenny. Rob regaled us with some 
really hilarious tales that were part and parcel of his family's history. The one I remember to this day was about a legendary great-uncle who went around one night after a night in the local pub and nailed all his neighbour's outdoor toilets shut.

Perhaps like you, reader, iI couldn't wait to meet them next time. Sarah indeed had been hilarious and I suspect she had gone all out to show the Problem not only how to have a good time but to bust everyones' sides laughing. And Kelly was far more animated than I had ever seen her telling me all about it.

David: Kelly, can you guess if the 'killjoy' Problem has lightened up a bit since you and your family are showing it your Irish humour? What do you think?

Kelly: I think so.

David: Why do you say that? Has the Problem been able to go out of the toilet and get around a bit more and perhaps meet some other Problems it could befriend? There are sure a lot of Problems around these days, aren’t there?

Rob: Sure are!

Jan: And you know, David, Kelly is having a lot more fun too.

David: Kelly, now that the Problem isn't living in the toilet all the time and kill-joying your fun, do you find you don't have to spend so much time in there keeping the Problem company? Have you heard the saying: 'Misery loves company'?

Kelly: No.

David: Jan or Rob, can you explain that saying to her?

Jan: What it means, I think, is misery doesn't like fun company, it just likes miserable company.

David: Kelly, have you been showing the Problem how to be fun company by having some fun and showing it how you do it so it can follow in your footsteps?

Kelly: Was bemused and well as confused by my query but Jan and Rob were quick to point out a myriad of examples of their daughter getting out and around a lot more and regaining some of her old friends and indeed, making a few new ones. I could tell from the look on their faces that they were experiencing considerable relief from this turn of events. They had had three or four what we referred to as 'comedy shows' as they called them in the toilet. I wondered aloud if the next step was a mixture of showing and telling. Of course, everyone wondered about how to go about this.

Kelly, since you love cats and dogs so much, when I was in the Auckland Central Library, this book just popped right up in front of me, almost as it if wanted me to take it out. When I looked at the title, I realized why. It is The New Yorker Book of Dog Cartoons.

We all decided that although a funny 10 year old like Kelly could understand quite a few of them, it might have to be a family affair to figure the jokes out so Kelly could tell the 'killjoy' Problem so "it could get the joke”. They decided to head back to the toilet on regular occasions, especially if the 'killjoy' Problem "just wasn't getting it" to show and tell the joke to it. It might need some explanation as it was very likely that some jokes might go over the Problem's head. And some cartoons 
might have to be saved for a while until the Problem grew up and understood more. I had to admit we had a lot of fun looking at some of the cartoons and figuring out what was so funny about them. Kelly was relieved to learn that there were some 'New Yorker Book of Cat Cartoons' if she felt sorry for cats being made so much fun of in the New Yorker dog cartoons. She acknowledged a preference for dogs but stated categorically that she also loved cats. Jan said she would pop in to her local library to either get or order the cat cartoon book as she was worried like I was that the dog cartoons were somewhat prejudiced about cats.

We continued to meet monthly to review how Kelly was doing lending the 'killjoy' Problem a hand. She was doing such a good job of it that the Problem had been downgraded from a 'killjoy' to 'worries' at our fourth meeting together. Kelly came up with the name this time without much hesitation.

Jan, now seemingly delivered of her burdens, spoke of her daughter in a very different tenor. "We are seeing this year which sport Kelly really likes. She is really enjoying tennis and doing very well at it. From my point of view, it is really lovely to see. She is so enthusiastic and although the worries are a little bit bad, they are nothing like they were. And we tend to forget just how far you have come, Kelly. I think she has done very well! (looking towards Ron who nods his head in the affirmative). Now her friends are coming over again and she goes to the toilet and comes out again”. Kelly, who was highly engaged in our conversation, took over without any hesitation: "I probably come out of the toilet quicker when I am having fun out of the toilet. I just go to the toilet when I need to go". To further enquiries of mine, she asserted that "I think it is really annoying when the worries are trying to annoy me when I want to go outside and play". In a spirited conversation, I asked: "Given that the worries were taking up a lot of your time and bothering you, does that mean you are having more fun and the worries are no longer killing you joys?". She assured one and all that was definitely the case. "Do you think they were punishing you for something?" "Yah, kind of". Jan chimed in with..." "And they make you say 'I can’t..I can’t do this!' all the time, don't they? Whereas we all know you can!”. “Jan, do you have any suspicions why the worries don't want Kelly to express all her abilities and talents to the full?”. Jan replied: "I think they are lying to her". "I don't know about you but it looks to me like the worries are getting afraid of her. Can you see any signs of her worrying the worries?”. Rob eagerly joined us: "The fact that she is playing tennis, having her friends around and getting out and around surely must mean the worries are getting worried". Turning to Kelly, I wondered aloud: "Do you think you might have to lend the worries a hand again to coach them on how to be calm, cool and collected?". Kelly grinned indicated that this might be something to put on her 'to do' list. "Kelly, if there was $100 \%$ of your life, what percentage would you say was fun-filled and what percentage was worry-filled?". "Yeah, it's kind of half of the time its good and half of the time it's bad so it is getting a lot better than what it was. And when I get tired, they tell me I am not making any progress and I can’t do this”. "Say before 
you were going to bed one night, have you ever told the worries off? I remember your mum telling me that she was very angry that the worries were stopping you reading". "Well with the reading, it is getting better, because 'Oh no, I want to keep reading. The book is too exciting!". Everyone laughed uproariously. "And that is the same when I am having fun. I want to have more fun!”. Jan requested Kelly tell me about when her friend, Rosy, visited recently. She happily launched herself in to her account: "My friend, Rosy and I were playing Pictionary and I went to the toilet and I got out pretty quickly. And then we just carried on playing". "Did this have to do with your preference for fun and friendship? Did this have to do with you teaching the worries to have more fun? Or a bit of both?". "Maybe. I think it was more the fun because Rosy and I were playing and having fun". "Did the worries still try to make you worry?”. "Well, I think they tried. Even when I am having fun they still try to make me worry and not come out".

"What did you do so they don't kill the joys you were having with Rosy?”. "I think I might have been ignoring them a little bit so there were still there telling me I should use more toilet paper. But I didn't listen to them because I just wanted to get out and play. Because that is what I do. I will be thinking what I can do when I get out kind of. So that it will be FUNNNNN when you get outside quickly". I summarized all the above as our meeting was coming to an end. At the end of my summary which everyone sanctioned as a fair record of events, I asked Kelly:

"If the worries knew you like Auntie Sarah knows you and your mum and dad know you, do you think it has got the wrong person, a possible case of mistaken identity, when it thinks you are a worry-wart but your dad thinks of you 'as full of life now' and your mum thinks of you as 'a sporty girl'? Who do you think knows you better- Auntie Sarah, your dad, your mum or the worries? Who do you think loves you the most?". She turned and met her parents' eyes, all of which were tearing up: "They do!". "Do you think you also might have to lend the Problem a hand about being a loving friend and daughter?”. Once again, she smiled at the prospect of yet another humanitarian mission.

Several months passed by and we met one last time to wrap up. In a detailed discussion, Kelly, thanks to her charitable nature, had decided the 'killjoy' Problem was no longer a killjoy and the worries were no longer so worrisome.

David: Kelly, now that the 'killjoy' Problem has retired from killing your joys and your family's joys, do you think you should tell the Problem off for doing what it used to do? Or do you think you should forgive it.

Kelly (answering without her usual time given to consideration): No, I want to forgive it.

David: Kelly, why do you want to forgive the Problem. After all it had spoiled a fair bit of your eight year old, nine year old and ten year old girl fun, had it not? At least that is what your mum and dad told me when we first met.

Kelly: It didn't know what it was doing. It didn't really mean it.

David: Really! You don't say! Jan and Rob, have you heard that before. 
Jan/Rob(as bemused as I was) No!

Kelly: I have forgiven it. How could it have known any better? It just didn’t know how to have fun.

David: Kelly, do you think a day will come when this retired Problem will say thanks to you for lending it a hand?

Kelly (grinning): Yah, I suppose so!

We all parted company in the best possible good humour, especially after we all agreed that if there was a time in the future when a problem tried to 'kill anyone's joys', they would just have to teach it a lesson similar to this one. And if that didn't work, we would reconvene and 'have a good laugh' together (Marsden, Epston, \& Markham, 2016).

Leonard Cohen, poet and musician, was awarded the Prince of Asturias Prize for Literature in Spain by the king and queen in 2011. He delivered an address entitled 'How I got my song”. Within it, he tells how he found his voice.

He tells the audience:

You know of my deep association and confraternity with the poet, Federico Garcia Lorca. I could say when I was a young man, an adolescent I hungered for a voice but I could not find a voice. It was only when I read, even in translation, the works of Lorca, I understood there was a voice. It was not that I copied his voice; I would not dare. But he gave me permission to find a voice, to locate a voice, that is to find a self is not fixed, that struggles for its own existence. And as I grew older, I knew that instructions came with this voice. What were these instructions? Never to lament casually. And if one is to express the great inevitable defeat that awaits us all, it must be done within the strict confines of dignity and beauty (Cohen, 2011). I believe that we are charged with the same ethical instructions. If we are to assist those who seek our assistance, it must be done in the same strict confines of dignity and beauty so that when they face the vicissitudes of life, a time when anyone would want to have available to them their moral character, they should not have been stripped of it naked.

I am just going to finish with an account of David, a twelve year old boy whom, when I first met him, had acquired a diagnosis of anorexia nervosa. He brought this document to declare at the tenth and last session. This is what he had written and read aloud:

Apology From Anorexia To Myself:

I am writing this apology to myself because even though I might dream about it, even though I thoroughly deserve it, even though you had stolen every pleasure I had in my life, I know you are so heartless, so shallow, so ruthless that you would never have the compassion or decency to make the apology for so long you have owed me. So I have written it for you. Here it is:

David, I am sorry that I have stolen your life form you. I am sorry for 
turning every pleasure you once had in your joyful life in to an unbearable torture from you pleasure to eating to your good company and to your sport. I made you hate yourself and see fault in everything you were and did. I took away your happiness and turned everything in to a horrible ordeal. I sapped all your strength turning you in to a lifeless body without a soul. I deprived you of all the tastes you enjoyed and stole 15 kilogrammes from you turning you in to an unhappy skeleton. I lied to you telling you I would make you happy and an overall better person. When you did what I said, I was ruthless and pushed your face in to the mud making you hate yourself and blame yourself for things I had tortured you in to doing.

It is obvious it would be impossible to fix what I have done to you but I will do all I can to fix what I have done. You deserve this apology and more. I am truly sorry. Yours anorexia.

Thank you.

\section{Notas:}

1. This Keynote Address was delivered $19^{\text {th }}$ June, 2015 in San Antonio, Texas at the ClarityCon Mental Health Summit.

2. Pasteur, L. (1854). Lecture, University of Lille.

3. This is excerpted from Chapter 1, pages 5-17 of Marsden, Epston and Markham(2016)

4. An English version of 'Reclaiming the Honour of Your Ancestors' is available at Narrative Therapy Archives at www.narrativeapproaches.com

5. Personal correspondence (2008).

\section{References}

Aristotle(W. Rhys Roberts, translator) (1984). The Rhetoric and Poetics of Aristotle. New York, NY: Modern Books. Cohen, L. (2011). Award Collection Speech. In Princess of Asturias Awards, Fundación Princesa de Asturias, Oviedo, Spain.

Epston, D. (2009, October). Putting Pressure on Yourself to Put Pressure on the Problem. Context.

Forster, E. M. (1956). Aspects of the Novel. London, United Kingdom: Mariner Books.

Frank, A. (2004). Moral Non-Fiction: Life Writing and Children’s Disability. In P. J. Eakin (Ed.), The Ethics of Life Writing (pp. 174-194). Ithaca, NY: Cornell University Press.

Kleinman, A. (1989). The Illness Narratives: Healing, Suffering and the Human Condition. New York, NY: Basic Books.

Lawrence-Lightfood, S. \& Davis, J. H. (1997). The Art and Science of Portraiture. New York, NY: John Wiley and Sons.

Marsden, D., Epston, D., \& Markham, L. (2016). Narrative Therapy in Wonderland: Connecting with Children's Imaginative Know-how. New York, NY: Norton.

Nelson, H. L. (2001). Damaged Identities, Narrative Repair. Ithaca, NY: Cornell University Press.

Whitaker, R. \& Cosgrove, L.(2015). Psychiatry Under the Influence: Institutional Corruption, Social Injuryand Prescriptions for Reform. London, United Kingdom: Palgrave Macmillan. https://doi.org/10.1057/9781137516022 